\title{
Real Life Comparison of Afatinib and Erlotinib in Non-small Cell Lung Cancer With Rare EGFR Exon 18 and Exon 20 Mutations: a Turkish Oncology Group (TOG) Study.
}

\section{Pınar Gürsoy ( $\sim$ pinargursoy77@gmail.com )}

Ege University: Ege Universitesi https://orcid.org/0000-0003-1392-6753

\section{Ali Murat Tatı}

Akdeniz University: Akdeniz Universitesi

\section{Dilek Erdem}

Medical Park Hospital SAMSUN

\section{Erdem Goker}

Ege University Faculty of Medicine: Ege Universitesi Tip Fakultesi

\section{Emir Çelik}

Cerrahpasa Medical School: Istanbul Universitesi-Cerrahpasa Cerrahpasa Tip Fakultesi

\section{Nebi Serkan Demirci}

Cerrahpasa Medical School: Istanbul Universitesi-Cerrahpasa Cerrahpasa Tip Fakultesi

\section{Abdullah Sakin}

Prof Dr Cemil Tascioglu City Hospital: Prof Dr Cemil Tascioglu Sehir Hastanesi

\section{Muhammed Mustafa Atçı}

Prof Dr Cemil Tascioglu City Hospital: Prof Dr Cemil Tascioglu Sehir Hastanesi

\section{Ertuğrul Bayram}

Cukurova University Faculty of Medicine: Cukurova Universitesi Tip Fakultesi

\section{Tuğba Akın Telli}

Marmara Universitesi Egitim ve Arastirma Hastanesi

\section{Burak Bilgin}

Ataturk Chest Diseases and Chest Surgery Training and Research Hospital: Ankara Kecioren Sanatoryum Ataturk Gogus Hastaliklari ve Gogus Cerrahisi Egitim ve Arastirma Hastanesi

Ahmet Bilici

?stanbul Medipol Üniversitesi: Istanbul Medipol Universitesi

\section{Baran Akagündüz}

Erzincan University: Erzincan Binali Yildirim Universitesi

\section{Sevinç Ballı}

Ankara University Faculty of Medicine: Ankara Universitesi Tip Fakultesi

\section{Ahmet Demirkazık}


Ankara University Faculty of Medicine: Ankara Universitesi Tip Fakultesi

\section{Fatıh Selcukbiricik}

Koç University: Koc Universitesi

\section{Serkan Menekşe}

Manisa Devlet Hastanesi

\section{Eyyup Cavdar}

Namık Kemal Üniversitesi Tip Fakültesi: Namik Kemal Universitesi Tip Fakultesi

\section{Akın Öztürk}

Sureyyapasa Chest Diseases and Chest Surgery Training and Research Hospital: Saglik Bakanligi Istanbul Sureyyapasa Gogus Hastaliklari ve Gogus Cerrahisi EA Hastanesi

\section{Esma Türkmen Bekmez}

Health Sciences University Derince Training and Research Hospital: Saglik Bilimleri Universitesi Derince Egitim Arastirma Hastanesi

\section{Serdal Turhal}

Anadolu Sağlık Merkezi: Anadolu Saglik Merkezi

\section{Saadettin Kılıçkap}

Hacettepe Universitesi Tip Fakultesi

\section{Hasan Çağrı Yıldırım}

Hacettepe Üniversitesi: Hacettepe Universitesi

\section{Başak Oyan}

Acıbadem altunizade hospital

\section{Asude Aksoy}

Fırat Üniversitesi Tıp Fakültesi: Firat Universitesi Tip Fakultesi

Fatma Paksoy TURKOZ

Medical Park goztepe Hospital

\section{Engin Kut}

Manisa Devlet Hastanesi

\section{Nuran Katgı}

Doktor Suat Seren Gogus Hastaliklari ve Cerrahisi Egitim ve Arastirma Hastanesi

\section{Teoman Sakalar}

kahramanmaraş necip fazıl city hospital

\section{Murat Akyol}

Bakırçay Üniversitesi: Bakircay Universitesi

\section{Halil Ibrahim Ellez}

Dokuz Eylul University Faculty of Medicine: Dokuz Eylul Universitesi Tip Fakultesi

\section{Atakan Topcu}

Bezmialem Vakif University: Bezmialem Vakif Universitesi

\section{Atike Pınar Erdoğan}

Celal Bayar University: Manisa Celal Bayar Universitesi 


\section{Kezban Nur Pilancı}

: Memorial bahcelievler Hospital

\section{Engin Hedem}

Necmettin Erbakan University: Necmettin Erbakan Universitesi

\section{Hacı Arak}

Gaziantep Universitesi Tip Fakultesi

\section{Nadiye Akdeniz}

Adıyaman training and research hospital

\section{Özkan Alan}

tekirdağ city hospital

\section{Burcu Yapar}

Pamukkale University School of Medicine: Pamukkale Universitesi Tip Fakultesi

\section{Deniz Nart}

Ege University Faculty of Medicine: Ege Universitesi Tip Fakultesi

\section{Perran Fulden Yumuk}

Koç University: Koc Universitesi

\section{Research Article}

Keywords: Exon 18, Exon 20, Erlotinib, Afatinib, NSCLC

Posted Date: December 10th, 2021

DOI: https://doi.org/10.21203/rs.3.rs-1125056/v1

License: (1) This work is licensed under a Creative Commons Attribution 4.0 International License. Read Full License

Version of Record: A version of this preprint was published at Journal of Cancer Research and Clinical Oncology on April 5th, 2022. See the published version at https://doi.org/10.1007/s00432-022-03984-5. 


\section{Abstract}

Objectives To compare the survival of first- and second-generation tyrosine kinase inhibitors (TKIs) in patients with rare EGFR exon 18 and exon 20 mutation-positive non-small cell lung cancer (NSCLC).

Materials and Methods We retrospectively evaluated survival characteristics of 125 patients with EGFR exon 18 and exon 20 mutated NSCLC who received erlotinib or afatinib as first line treatment between 2012 and 2021 from 34 oncology centres. Since exon 20 insertion is associated with TKI resistance, these 18 patients were excluded from the study.

Results EGFR exon 18 mutations were seen in $60 \%$, exon 20 mutations in $16 \%$, and complex mutations in $24 \%$ of the patients with NSCLC who were evaluated for the study. There were 75 patients in erlotinib treated arm and 50 patients in afatinib arm. Patients treated with erlotinib had progression-free survival time (PFS) of 8.0 months and PFS was 7.0 months in the afatinib arm $(p=0.869)$, while overall survival time (OS) was 20.0 vs 24.8 months, respectively ( $p=0.190$ ). PFS of exon 18 mutated arm was 7.0 months, exon 20 mutated arm was 4.3 months, and complex mutation positive group was 17.3 months, and this was statistically significant $(p=0.036)$. The longest OS was 32.5 months, seen in the complex mutations group, which was not statistically different than exon 18 and in exon 20 mutated groups (21.0 and 21.2 months, respectively) $(p=0.323)$.

Conclusion In this patient group, especially patients with complex mutations are as sensitive to EGFR TKI treatment similar to classical mutations, and in patients with rare exon 18 and exon 20 EGFR mutation both first- and second-generation EGFR-TKIs should be considered, especially as first- and second-line options.

\section{Introduction}

Non-small cell lung cancer (NSCLC) is the most common cause of cancer-related deaths worldwide (Herbst et al 2008). Frequency of epidermal growth factor receptor (EGFR) mutation in patients with NSCLC has been found to be approximately $10-20 \%$ in European populations and $50 \%$ in Asian populations (Yuankai et al 2014). Exon 19 and exon 21 L858R are called "classical EGFR mutations" and account for $90 \%$ of EGFR mutations in all NSCLC (Rafael et al 2009). These classical EGFR mutations show high sensitivity to tyrosine kinase inhibitors (TKIs). In studies comparing TKIs with chemotherapy, it has been shown that patients treated with TKIs have longer progression-free survival (PFS) (Rafael et al 2012).

Other EGFR mutations are called uncommon EGFR mutations (u-EGFRm), and these account for approximately $10-20 \%$ of all EGFR mutations. Among the u-EGFR mutations, exon 18 and exon 20 mutations were found to be $2-4 \%$ and $4-5 \%$, respectively (Rafael et al 2010 ; Kobayashi et al 2013). Clinical characteristics, their response to TKIs and prognosis of u-EGFRm positive patients are not completely clear (Pao et al 2010 ; Mitsudomi et al 2006) 
Among the TKIs, erlotinib is a first-generation reversible TKI, while afatinib is a second-generation irreversible TKI. Erlotinib in the OPTIMAL study and afatinib in the LUX-LUNG-3 study showed PFS advantage over standard chemotherapy (Zhou et al 2011; Sequist 2012). There are no clinical study comparing the efficacy of erlotinib and afatinib in patients with both "classical EGFR mutations" and "uncommon mutations" in the literature.

The aim of this study is to determine the characteristics of advanced stage NSCLC patients with EGFR exon 18 and 20 mutations, and to reveal the survival outcomes of patients treated with first- and secondgeneration TKI in NSCLC harbouring these rare mutations.

\section{Materials And Methods}

\section{Study design}

In our study, the data of 143 patients with NSCLC who were positive for EGFR exon 18 and exon 20 mutations treated with erlotinib or afatinib in 34 centers from Turkey between 2012-2021 were evaluated retrospectively. EGFR mutation positivity in patients with NSCLC was determined by pyrosequencing method or real time PCR. Since exon 20 insertion is associated with TKI resistance, these 18 patients were excluded from the study. However, we wanted to specify the data of 18 patients separately. Remaining 125 patients included in the study were divided into 3 groups. The first group consisted of patients with only exon 18 mutations, the second group with only exon 20 mutations, and the third group with complex mutations. Complex mutation was defined as more than one mutation positivity on the condition with one of the mutations was seen on exon 18 or exon 20. Flow chart of the study is presented in Figure 1. Sex, age, smoking status, ECOG performance score (PS), stages, metastasis sites, treatments received before and after, side effects, date of progressive disease and death of the patients were recorded. Progression-free survival (PFS) was defined as the time between the onset of TKI and the date of progression, or death, and overall survival (OS) was defined as the time between the date of diagnosis and the date of death or the last contact date. Among these 3 groups, general characteristics of the patients, survival outcomes, and relationship between the survival time and the type of TKI treatment were evaluated retrospectively.

\section{Statistical analysis}

IBM SPSS Statistics Version 22 package program was used for statistical analysis. Whether the data was normally distributed was determined by Kolmogorov-Smirnov and Shapiro-Wilk tests. Mann-Whitney U test was used to compare continuous variables between groups, Chi-square test and Fisher's exact test were used to compare categorical variables. Kaplan-Meier test was used for survival analysis. Results are presented as, median (min-max) and number (percentage). A p value of $<0.05$ was considered statistically significant in all statistical analyses.

\section{Results}




\section{Patients}

Median age of 125 patients was 63.1 (37.0-86.0). Exon 18, exon 20 and complex mutations rates were $60 \%$ (75 patients), 16\% (20 patients) and 24\% (30 patients), respectively. Exon 18 and complex mutations were observed more in males, and the frequency of exon 20 mutations was equal in both genders $(p=0.196)$. There were 75 patients $(60 \%)$ treated with erlotinib and 50 patients $(40 \%)$ with afatinib. EGFRTKI was the first line treatment in $53.6 \%$ of the patients, second line in $39.2 \%$, third line in $6.4 \%$ and fourth line in $0.8 \%$. General characteristics of the patients are presented in Table 1.

\section{Survival outcomes}

The median follow-up time of all patients was 16.7 months (1.3-112.7). Follow-up period was 16.5 months in the erlotinib arm and 17.4 months in the afatinib arm.

OS of all patients was 21.4 months ( $95 \% \mathrm{Cl}$ : 16.1-26.6), while PFS was 7.2 months ( $95 \% \mathrm{Cl}$ : $5.1-9.3)$. When PFS and OS were compared according to the type of TKI used, PFS was 8.0 months (95\%Cl: 4.7-11.3) in the erlotinib arm and 7.0 months $(95 \% \mathrm{Cl}: 4.4-9.6)$ in the afatinib arm. OS seemed longer in the afatinib arm than in the erlotinib arm (24.8 months vs. 20.0 months, respectively). However, no statistically significant difference was found between the two groups in both PFS and OS comparisons (Figure 2A,2B).

PFS in the Exon 18, Exon 20 and complex mutation groups were 7.0 months $(95 \% \mathrm{Cl}$ 5.9-8.1), 4.3 months $(95 \% \mathrm{Cl} 2.1-6.5)$ and 17.3 months $(95 \% \mathrm{Cl} 8.5-26.1)$, respectively, and there was a statistically significant difference between these 3 groups $(p=0.036)$ (Figure 3 ).

The distribution of rare mutations is presented in figure 4 .

Exon 18 G719X point mutation was the most mutation. This mutation was found alone in $85 \%$, and it was also found together with exon 19 deletion in $3 \%$ and with exon 21 mutation in $12 \%$ of patients. Thirty-six exon 18 G719X positive patients received erlotinib and 24 patients received afatinib. The survival rates are shown in Table 2.

When insertions of exon 20 was excluded, the second most common mutation was S768l, which was usually positive alone. Nine patients with this mutation received erlotinib and 6 received afatinib (Table 2).

When the PFSs were evaluated according to the TKI types of the patients in the exon groups, statistical significance was not found in all groups, although the PFS was longer in those who received afatinib than those who received erlotinib. Similar results were also observed in OS. The results are presented in Table 2.

When OSs were compared according to exon subgroups, the longest OS was found to be 32.5 months in complex mutations, while it was 21.0 and 21.2 months seen in Exon 18 and exon 20 mutations, respectively $(p=0.323)$. 
Exon 19 or exon 21 mutations were present in 22 patients in the complex mutation group, and PFS time of these patients was 17.4 months (95\% Cl 6.6-28.2) and OS was 24.3 months (95\% $\mathrm{Cl} 0.0-89.4)$. In patients without exon 19 and/or exon 21 alterations, PFS was 8.3 months ( $95 \% \mathrm{Cl} 0.0-21.4)$ and OS was 11.5 months (95\% Cl 0.0-42.5). In the complex mutation group, there was no difference in terms of PFS and OS between erlotinib or afatinib treatments, regardless of exon 19 or exon 21 status.

Overall response rate of the patients was similar in the erlotinib and afatinib arms $(53.3 \%$ vs $52 \%, p=$ 0.218) (Table 3).

There was no difference between the TKI treatment groups in terms of gender and metastatic status. In the erlotinib arm, PFS of the patients who had never smoked was statistically longer than those who were ex-smokers and current smokers (12.0 vs 8.0 vs 3.5 months, $p=0.008)$, while no statistical difference was found in the afatinib arm (9.6 vs 6.0 vs 8.5 months, $p=0.087)$.

There were no difference between the exon groups, when sex and metastasis status were compared. However, in exon 18 mutation-positive patients, the PFS was longest in the never-smoker group, and a statistical difference was found compared to the patients who quit smoking and are still smoking (9.6 vs 6.6 vs 3.7 months, $p=0.013$ ). There were no PFS difference between smoking status in exon 20 and complex mutations (p:0.118 vs p:0.331)

Patients received TKIs mostly as first line treatment, and the PFS in the first line was 8.9 months, 7.1 months in the second line, 3.4 months in the third line, and 3.5 months in the fourth line $(p=0.009)$. There were no OS difference between the line of treatment $(p=0.233)$.

\section{Results of patients with exon 20 insertion}

Since exon 20 insertion is associated with TKI resistance, this mutation was analysed in itself. Of those 18 patients with exon 20 insertion, 10 patients were male, and 50\% were non-smokers. In this group, 7 patients (38.3\%) received erlotinib, 6 patients (33.3\%) afatinib, and 5 patients (27.7\%) gefitinib. Median PFS of the whole group was 8.7 months (95\% $\mathrm{Cl} 3.1-14.3)$. In those who received erlotinib PFS was 7.0 months (95\% Cl 1.0-14.2), in afatinib treated patients PFS was 8.7 months (95\% Cl 1.0-20.5), and in gefitinib 15.0 months (95\% Cl 1.0-24.1) ( $p=0.479)$. Median OS was 26.4 months (95\% $\mathrm{Cl} 20.0-32.8)$ for the entire group. It was 24.0 months $(95 \% \mathrm{Cl} 20.7-27.3)$ with erlotinib, 31.4 months (95\% Cl 22.7-40.1) with afatinib, and 28.5 months (95\% Cl 11.1-46.0) with gefitinib. There was no statistically significant difference between the TKIs. In this patient group, only the PFS values of male patients were found to be significantly longer than female patients (12.0 months vs. 3.2 months, $p=0.003)$.

\section{Safety}

Most common adverse event in the erlotinib arm was rash (54.6\%), followed by mucositis (41.3\%), anemia (32.0\%), diarrhea (28.0\%), and elevated transaminase (20\%). Rash (66\%), diarrhea (58\%), anemia (36\%), mucositis (28\%), and elevated transaminases (24\%) were observed frequently with afatinib. 
The incidence of grade $3-4$ adverse events was $13.3 \%$ in the erlotinib arm, and $20 \%$ in the afatinib arm. Due to side effects, treatment was interrupted in 20 (16.0\%) patients and dose reduction was made in 17 (13.6\%) patients. In 7 patients (5.6\%), the treatment was permanently discontinued. Side effects that led to treatment discontinuation were rash, elevated transaminases, and interstitial lung disease. Interstitial lung disease was observed only in 1 patient (2\%) with afatinib, and treatment was permanent discontinued.

When the relationship between side effects and survival was evaluated, PFS was longer in patients with mucositis (14.2 months vs. 6.0 months, $p=0.004)$, and OS was longer in patients with rash (24.7 months vs 17.8 months, $p=0.080)$.

\section{Discussion}

In our study, no difference was found in terms of survival when first- and second-generation EGFR-TKIs were compared in NSCLC patients with rare mutations in exon 18 and exon 20. In addition, the complex EGFR mutations which were almost one fourth of our study group showed the highest sensitivity to the TKls treatment.

In the literature, there is only one study in which 18 patients were retrospectively compared first- and second-generation TKI treatments in patients with NSCLC carrying uncommon EGFR mutations ( Tanaka et al 2019) In this study, there was a significant PFS difference in favour of afatinib compared to erlotinib (17.1 and 5.5 months respectively, $p=0.048$ ). However, in this small study differences between mutation subtypes were not specified.

Most common rare mutation in our patient group was exon 18 mutations. Although PFS was longer in patients treated with afatinib, no statistically significant difference was found when compared with erlotinib. G719X point mutation on exon 18 was detected in $56 \%$ of the whole group. It was seen alone in $85 \%$, and was together with exon 19 deletions in $3 \%$ and exon 21 mutations in $12 \%$ of patients. Although G719X is the most common point mutation in the literature, it has been reported that it is associated with complex mutations at a rate of $90 \%$ (Passaro et al 2020). In the post-hoc analysis of LUX-lung 2, LUXlung 3 and LUX-lung 6 studies, PFS was 13.8 months, OS 26.9 months, and Objective Response Rate (ORR) was $78 \%$ in patients receiving afatinib with G719X mutation (Sequist et al 2012). In a retrospective study by Chiue, PFS was 6.5 months and ORR $50 \%$ with erlotinib/gefitinib treatment in this patient group (Chiu et al 2015). In our study, it was observed that G719X positive patients had a shorter PFS and a lower ORR compared to the literature. We think that this may be due to the low number of patients with other mutations accompanying the G719X mutation in our study.

S768I mutation in exon 20 is the second most common mutation, when exon 20 insertion is excluded (Sun et al. 2009). In accordance with the literature, this mutation was usually found alone in our study. In Zhang's retrospective study, although the ORR was $27.3 \%$ in patients receiving erlotinib, PFS was found to be 8.0 months (range 4.3-11.8 months). According to the post-hoc analysis results of the LUX-lung 2-3-6 studies, the S768I mutation had the longest PFS duration (14.7 months). In our study, although PFS and 
ORR of those who received erlotinib were similar to the literature, very short PFS values were seen with afatinib. Having said that, 34.7 months of OS was seen with afatinib in this subgroup.

The frequency of complex mutations is approximately $25 \%$ according to the latest data, and it was also seen in our study as $24 \%$ (Kim et al. 2016). Complex mutations have been shown to respond better to EGFR-TKIs compared to single rare mutations. Especially its co-occurrence with exon 19 del or L858R mutations might be a strong indicator of its sensitivity to EGFR-TKIs. In our study, the PFS and OS values of patients having complex mutations with exon 19 deletions or exon 21 mutations were also longer than those without. In a retrospective study by Keam et al, complex and classical mutations showed the same treatment efficacy to EGFR-TKI (Kem et al.2014). In the multicenter study of Passaro et al, TKI response of patients with complex mutations was superior in terms of both PFS and OS compared to patients with exon 18 mutations (Passaro et al. 2019). In our study, a statistically significant PFS advantage was observed in patients with complex mutations compared to only exon 18 or exon 20 mutated patients.

Some of the preclinical studies have shown that second generation TKIs are more effective in rare mutations than first- and third- generation TKls (Gristina et al 2020). Tanaka et al. compared afatinib with first generation TKIs in patients with complex mutations. The authors reported a statistically longer PFS and a better ORR in favor of afatinib (Tanaka et al.2019). Similar to the literature, we also found a nonsignificant longer PFS with afatinib than erlotinib. This might be secondary to low number of patients in both treatment groups.

Recent studies on rare mutations are summarized in Table 4.

Exon 20 insertion in the tyrosine kinase domain is located after the C-helix, it is assumed to be resistant to EGFR-TKIs. In this subtype, the contribution of chemotherapy to PFS is 5 months, while the contribution of TKI to PFS is around 2.5 months. It has been suggested that exon 20 insertion excludes another EGFR mutation (Wu et al. 2008). However, there are cases of exon 20 insertion seen with exon 19 deletion and L858R mutation in the literature. In that case, survival times were observed to be longer with TKI treatment. In a retrospective study evaluating 77 patients, ORR was $24.3 \%$, and PFS was 11.9 months with afatinib (Yang et al.2019). These data suggest that some exon 20 insertions seen as a part of complex mutations are clinically sensitive to afatinib. Nevertheless, PFS was found to be 2.7 months in the LUX-lung studies, and variants sensitive to TKIs may not have been represented at a high rate due to the high heterogeneity of exon 20 insertion in these studies. In a study from Korea, PFS was found to be 11.4 months in a patient with only exon 20 insertion. The reason for this was stated that different variants in the amino acid sequence might affect the response to treatment (Byeon et al 2019). Kosaka et al. showed that replacing Asp770 with Gly770 restored susceptibility to EGFR TKIs by allowing access to Arg776 ( Kosaka et al 2017). In our study, PFS value of this group was found to be longer than the literature. In particular PFS values of 5 patients who received gefitinib were reported as the longest TKI responses in the literature, and exon 19 deletion or exon 21 mutation were also detected in only these 5 patients in the whole group. Exon 20 insertion combined with these mutations has a median PFS of 11.3 months. The reason for the long PFS in the literature might be the presence of these complex mutations 
or different variants which are very sensitive to TKIs. However, studies with a larger number of patients are needed to reveal these results clearly.

In our study, PFS of patients who received first- and second-line EGFR-TKIs was found to be statistically longer than those who received third-line and later. In the literature, PFS values are very short after the third line (Chiu 2015). Therefore, treatment of NSCLC with EGFR-TKI as first-line or second-line therapy is considered a reasonable option for patients with rare mutations.

Limitations of this study were that it was designed retrospectively, and the selected agents were the physician's preference and could affect the results. In addition, methods used in each center to detect the EGFR mutations might have affected the mutation frequency and positivity rate. Despite these limitations, our study has the largest number of patients in the literature comparing afatinib and erlotinib treatment in patients with rare exon 18 and exon 20 mutation. Although afatinib provided longer survivals in terms of treatment efficacy, no statistically significant difference was found. In this patient group, especially patients with complex mutations are as sensitive to EGFR TKI treatment as classical mutations, and in patients with rare exon 18 and exon 20 mutations, both first- and second-generation TKIs should be considered, especially as first- and second-line options.

\section{Declarations}

\section{Ethics Committee Approval}

This study was approved by Ethical Committee(21-4.1T_10_0). All patients gave written informed consent.

\section{Acknowledgements}

None

\section{Conflict of interest}

The authors declare no conflicts of interest

\section{Funding}

No role for any funding source

\section{References}

1. Herbst RS, Heymach JV, Lippman SM (2008) Lung cancer. N E J M 2008;359:1367-80.

2. Yuankai S, Joseph S-K-A, Sumitra T, Sankar S, Chun-Ming T, Mai T-K, et al (2014). A prospective, molecular epidemiology study of EGFR mutations in Asian patients with advanced non-small-cell lung cancer of adenocarcinoma histology (PIONEER). J Thorac Oncol 2014;9:154-62. 
3. Rafael R, Teresa M, Cristina Q, Rut P, Felipe C, Carlos C et al (2009) Spanish Lung Cancer Group. Screening for epidermal growth factor receptor mutations in lung cancer. N Engl J Med 2009;361:958-67.

4. Rafael R, Enric C, Radj G, Alain V, Bartomeu M, Enriqueta F et al (2012). Spanish Lung Cancer Group in collaboration with Groupe Français de Pneumo-Cancérologie and Associazione Italiana Oncologia Toracica. Erlotinib versus standard chemotherapy as first-line treatment for European patients with advanced EGFR mutation-positive non-small-cell lung cancer (EURTAC): a multicentre, open-label, randomised phase 3 trial. Lancet Oncol 2012;13: 239-46.

5. Rafael R, Santiago V, Susana Benlloch, Miquel Taron(2010). Epidermal growth factor receptor tyrosine kinase inhibitors as first-line treatment in advanced nonsmall-cell lung cancer. Curr Opin Oncol. 2010 Mar;22(2):112-20.

6. Kobayashi S, Canepa HM, Bailey AS, et al (2013). Compound EGFR mutations and response to EGFR tyrosine kinase inhibitors. J.Thorac Oncol 2013;8:45-51.

7. Pao W. Chmielecki J (2010). Rational, biologically based treatment of EGFR-mutant non-small-cell lung cancer. Nat Rev Cancer 10, 760-774.

8. Mitsudomi T, Kosaka T, Yatabe Y(2006). Biological and clinical implications of EGFR mutations in lung cancer. Int J Clin Oncol 2006 Jun;11(3):190-8.

9. Zhou C, Wu YL, Chen G, Feng J, Liu XQ, Wang C et al (2011) Erlotinib versus chemotherapy as firstline treatment for patients with advanced EGFR mutation-positive non-small-cell lung cancer (OPTIMAL, CTONG-0802): a multicentre, open-label, randomised, phase 3 study. Lancet Oncol $12: 735-42$.

10. Sequist LV, Yang JC, Yamamoto N, O'Byrne K, Hirsh V, Mok T et al (2012). Phase III study of afatinib or cisplatin plus pemetrexed in patients with metastatic lung adenocarcinoma with EGFR mutations. J Clin Oncol 20;31 27: 3327-34.

11. Tanaka I, Morise M, Kodama Y, Matsui A, Ozawa N, Ozone S et al (2019) Potential for afatinib as an optimal treatment for advanced non-small cell lung carcinoma in patients with uncommon EGFR mutations. Lung Cancer 2019;127:169-71.

12. Passaro A, Mok T, Peters S, Popat S, Ahn M-J, Marinis F (2020) Recent Advances on the Role of EGFR TyrosineKinase Inhibitors in the Management of NSCLC With Uncommon, Non Exon 20 Insertions, EGFR Mutations. Journal of Thoracic Oncology Vol. 16 No. 5: 764-773.

13. Chiu C-H, Yang C-T, Shih J-Y, Huang M-S, Su W-C, Lai R-S et al (2015) Epidermal Growth Factor Receptor Tyrosine Kinase Inhibitor Treatment Response in Advanced Lung Adenocarcinomas with G719X/L861Q/ S768I Mutations.J Thorac Oncol 2015;10:793-9.

14. Sun JM, Lee KW, Kim JH, Kim YJ, Yoon HI, Lee JH et al (2009). Efficacy and toxicity of pemetrexed as a third-line treatment for non-small cell lung cancer. Jpn J Clin Oncol 39(1): 27-32, 2009.

15. Kim EY, Cho EN, Park HS, Hong J-Y, Lim S, Youn J-P et al (2016). Compound EGFR mutation is frequently detected with co-mutations of actionable genes and associated with poor clinical outcome in lung adenocarcinoma. Cancer Biol Ther. 2016;17:237-245. 
16. Keam B, Kim DW, Park JH, Lee J-O, Kim T-M, Lee S-H et al (2014) Rare and complex mutations of epidermal growth factor receptor, and efficacy of tyrosine kinase inhibitor in patients with non-small cell lung cancer. Int J Clin Oncol 2014;19:594-600.

17. Passaro A, Prelaj A, Bonanno L, Tiseo M, Tuzi A, Proto C et al (2019). Activity of EGFR TKIs in Caucasian Patients With NSCLC Harboring Potentially Sensitive Uncommon EGFR Mutations. Clin Lung Cancer 2019;20:e186-94.

18. Gristina V, Malapelle U, Galvano A, Pisapia P, Pepe F, Rolfo C et al (2020). The significance of epidermal growth factor receptor uncommon mutations in non-small cell lung cancer: a systematic review and critical appraisal. Cancer Treat rev.2020;85:101994.

19. Kobayashi Y, Mitsudomi T(2016). Not all epidermal growth factor receptor mutations in lung cancer are created equal: perspectives for individualized treatment strategy. Cancer Sci. 2016;107:11791186.

20. Kate S, Chougule A, Josh A, Noronha V, Patil V, Dusane R et al (2019). Outcome of uncommon EGFR mutation positive newly diagnosed advanced non-small cell lung cancer patients: a single center retrospective analysis. Lung Cancer (Auckl) 2019;10:1-10.

21. Yang J.C.H, Sequist L-V, Geater S-L, Tsai C-M, Mok T-S-K, Schuler M et al (2015) Clinical activity of afatinib in patients with advanced non-small-cell lung cancer harbouring uncommon EGFR mutations: a combined post-hoc analysis of LUX-Lung 2, LUX-Lung 3, and LUX-Lung 6. Lancet Oncol. 2015;16(7):830-838.

22. Wu J-Y, Shih J-Y(2016). Effectiveness of tyrosine kinase inhibitors on uncommon E709X epidermal growth factor receptor mutations in non-small-cell lung cancer. Onco Targets Ther. 2016; 9: 61376145.Published online 2016 Oct 11.

23. Chen D, Song Z, Cheng G (2016). Clinical efficacy of first-generation EGFR-TKIs in patients with advanced non-small-cell lung cancer harboring EGFR exon 20 mutations. Onco Targets Ther. 2016;9:4181-4186.

24. Xu J, Jin B, Chu T ,Dong X, Yang H, Zhang Y et al (2016) .EGFR tyrosine kinase inhibitor (TKI) in patients with advanced non-small cell lung cancer (NSCLC) harboring uncommon EGFR mutations: A real-world study in China. Lung Cancer.Volume 96, June 2016, Pages 87-92.

25. M. Beau-Faller, N. Prim, A.-M. Ruppert, I. Nanni-Metéllus, R.Lacave, L. Lacroix, F et al (2014). Rare EGFRexon 18 and exon 20 mutations in non-small-cell lung cancer on 10117 patients: a multicentre observational study by the French ERMETIC-IFCT network. Annals of Oncology25: 126-131, 2014.

26. Wu JY, Wu SG, Yang CH, Gow CH, Chang YL, Yu CJ et al (2008). Lung cancer with epidermal growth factor receptor exon 20 mutations is associated with poor gefitinib treatment response. Clin Cancer Res. 2008;14:4877-82.

27. Yang J-C-H, Schuler M, Popat S, Miura S, Heeke S, Park K et al (2019), Afatinib for the Treatment of NSCLC Harboring Uncommon EGFR Mutations: A Database of 693 Cases. J Thorac Oncol 2020 May;15(5):803-815. 
28. Byeon S, Kim Y, Won Lim S, Cho J-H, Park S, Lee J et al (2019). Clinical Outcomes of EGFR Exon 20 Insertion Mutations in Advanced Non-small Cell Lung Cancer in Korea.Cancer Res Treat. . 2019 Apr;51(2):623-631..

29. Kosaka T, Tanizaki J, Paranal RM, Endoh H, Lydon C, Capelletti M et al (2017). Response heterogeneity of EGFR and HER2 exon 20 insertions to covalent EGFR and HER2 inhibitors. Cancer Res. 2017;77:2712-22.

\section{Tables}

Table 1 Baseline clinical and demographic characteristics of patients 


\begin{tabular}{|c|c|c|c|c|}
\hline & $\begin{array}{l}\text { Patients, } \\
\text { n (\%) }\end{array}$ & $\begin{array}{l}\text { Patients with EGFR } \\
\text { exon } 18 \text { mutations, } \\
\text { n (\%) }\end{array}$ & $\begin{array}{l}\text { Patients with EGFR } \\
\text { exon } 20 \text { mutations, } \\
\text { n (\%) }\end{array}$ & $\begin{array}{l}\text { Patients with } \\
\text { complex EGFR } \\
\text { mutations, n (\%) }\end{array}$ \\
\hline & 125 & $75(60)$ & $20(16)$ & $30(24)$ \\
\hline $\begin{array}{l}\text { Age (years) mean } \\
\text { (min-max) }\end{array}$ & $\begin{array}{l}63.1 \pm 10 \\
6\end{array}$ & $62.7 \pm 10.6$ & $61.0 \pm 11.41$ & $65.4 \pm 10.0$ \\
\hline \multicolumn{5}{|l|}{ Sex, n (\%) } \\
\hline Female & \multirow{2}{*}{$\begin{array}{l}46 \\
(36.8) \\
79 \\
(63.2)\end{array}$} & $23(30.6)$ & $10(50.0)$ & $13(43.3)$ \\
\hline Male & & $52(69.3)$ & $10(50.0)$ & $17(56.6)$ \\
\hline \multicolumn{5}{|l|}{ Smoking, n (\%) } \\
\hline $\begin{array}{l}\text { Never smoker } \\
\text { Former smoker } \\
\text { Current smoker }\end{array}$ & $\begin{array}{l}59 \\
(47.2) \\
15 \\
(12.0)\end{array}$ & $\begin{array}{l}28(37.3) \\
37(49.3) \\
10(13.3)\end{array}$ & $\begin{array}{l}8(40.0) \\
8(40.0) \\
4(20.0)\end{array}$ & $\begin{array}{l}15(50) \\
14(46.6) \\
1(3.3)\end{array}$ \\
\hline \multicolumn{5}{|l|}{ Histology, n (\%) } \\
\hline $\begin{array}{l}\text { Adenocarcinoma } \\
\text { Squamous cell } \\
\text { Large cell } \\
\text { Mixt }\end{array}$ & $\begin{array}{l}116 \\
(92.8) \\
5(4.0) \\
1(0.8) \\
3(2.4)\end{array}$ & $\begin{array}{l}69(92.0) \\
4(5.3) \\
0 \\
2(2.6)\end{array}$ & $\begin{array}{l}19(95.0) \\
0 \\
1(5.0) \\
0\end{array}$ & $\begin{array}{l}28(93.3) \\
1(3.3) \\
0 \\
1(3.3)\end{array}$ \\
\hline \multicolumn{5}{|l|}{ ECOG, n (\%) } \\
\hline $\begin{array}{l}0 \\
1 \\
2\end{array}$ & $\begin{array}{l}22 \\
(17.6)\end{array}$ & $\begin{array}{l}17(22.6) \\
46(61.3) \\
11(14.6)\end{array}$ & $\begin{array}{l}3(15,0) \\
13(65,0) \\
1(5,0)\end{array}$ & $\begin{array}{l}2(6.6) \\
23(76.6) \\
5(16.6)\end{array}$ \\
\hline 3 & $\begin{array}{l}17 \\
(13.6) \\
4(3.2)\end{array}$ & $1(1.3)$ & $3(15,0)$ & 0 \\
\hline $\begin{array}{l}\text { Stage at } \\
\text { presentation, n } \\
(\%)\end{array}$ & $6(4.8)$ & $5(6.6)$ & $1(5)$ & 0 \\
\hline I & $6(4.8)$ & $4(5.3)$ & 0 & $2(6.6)$ \\
\hline II & $12(9.6)$ & $8(10.6)$ & $3(15)$ & $1(3.3)$ \\
\hline
\end{tabular}




\begin{tabular}{|c|c|c|c|c|}
\hline $\begin{array}{l}\text { III } \\
\text { IV }\end{array}$ & $\begin{array}{l}101 \\
(80.8)\end{array}$ & $58(77.3)$ & $16(80)$ & $27(90)$ \\
\hline \multicolumn{5}{|c|}{ Metastasis, n (\%) } \\
\hline Solitary & $\begin{array}{l}48 \\
(38.4)\end{array}$ & \multirow{2}{*}{$\begin{array}{l}33(44) \\
42(56)\end{array}$} & $5(25)$ & $10(33.3)$ \\
\hline Multiple & $\begin{array}{l}77 \\
(61,6)\end{array}$ & & $15(75)$ & $20(66.6)$ \\
\hline \multicolumn{5}{|c|}{$\begin{array}{l}\text { De-novo disease, } \\
\text { n (\%) }\end{array}$} \\
\hline Yes & $\begin{array}{l}101 \\
(80.0)\end{array}$ & 58 (77.3) & $16(80.0)$ & $27(90.0)$ \\
\hline No & $\begin{array}{l}24 \\
(20.0)\end{array}$ & 17 (22.6) & $4(20.0)$ & $3(10.0)$ \\
\hline \multicolumn{5}{|c|}{$\begin{array}{l}\text { Brain metastasis, } \\
\mathrm{n}(\%)\end{array}$} \\
\hline Yes & $\begin{array}{l}30 \\
(24.0)\end{array}$ & $18(24.0)$ & $6(30.0)$ & $6(20.0)$ \\
\hline No & $\begin{array}{l}95 \\
(76.0)\end{array}$ & $57(76.0)$ & $14(70.0)$ & $24(80.0)$ \\
\hline
\end{tabular}

Table 2 Comparison of survival times according to TKI type in Exon groups 


\begin{tabular}{|c|c|c|c|c|c|c|}
\hline Exon & TKI & $\mathrm{n}$ & $\begin{array}{l}\text { PFS (months) } \\
\text { (median) }\end{array}$ & $P$ value & $\begin{array}{l}\text { OS (months) } \\
\text { (median) }\end{array}$ & $P$ value \\
\hline \multirow[t]{2}{*}{ Exon 18} & Erlotinib & 45 & $5.6(2.9-8.3)$ & 0.206 & $23.9(11.2-36.7)$ & 0.691 \\
\hline & Afatinib & 30 & $7.0(4.3-9.7)$ & & $19.0(14.9-23.1)$ & \\
\hline \multirow[t]{2}{*}{ Exon 20} & Erlotinib & 13 & $4.0(0.4-7.6)$ & 0.966 & $16.7(10.4-23.0)$ & 0.417 \\
\hline & Afatinib & 7 & $4.3(1.8-6.8)$ & & $34.7(17.1-52.3)$ & \\
\hline \multirow[t]{2}{*}{ Complex } & Erlotinib & 17 & $11.7(7.2-16.2)$ & 0.674 & $20.0(6.6-33.4)$ & 0.133 \\
\hline & Afatinib & 13 & 18.7(6-31.4) & & $33.9(25.8-42.0)$ & \\
\hline \multirow[t]{2}{*}{ G719X } & Erlotinib & 36 & $4.9(1.0-8.7)$ & 0.328 & $17.3(12.5-22.0)$ & 0.489 \\
\hline & Afatinib & 24 & 8.8(6.7-10.8) & & $21.0(16.2-25.7)$ & \\
\hline \multirow[t]{2}{*}{ S768I } & Erlotinib & 10 & $9.7(0.0-23.6)$ & 0.111 & $16.7(11.8-21.4)$ & 0.566 \\
\hline & Afatinib & 5 & $3.1(1.1-5.02)$ & & $34.7(0-77.4)$ & \\
\hline \multirow{3}{*}{$\begin{array}{l}\text { Exon } 20 \\
\text { insertion }\end{array}$} & Erlotinib & 7 & $7.0(1.0-14.2)$ & 0.479 & $24.0(20.7-27.3)$ & 0.396 \\
\hline & Afatinib & 6 & $8.7(1.0-20.5)$ & & $31.4(22.7-40.1)$ & \\
\hline & Gefitinib & 5 & $15.0(1.0-24.1)$ & & 28.511.1-46.0) & \\
\hline
\end{tabular}

Table 3 Best response rates of afatinib and erlotinib

\begin{tabular}{|cll|}
\hline & Erlotinib (n:75) & Afatinib (n:50) \\
\hline Type of response(\%) & & \\
\hline Complete response & 5.3 & 6.0 \\
\hline Partial response & 48.0 & 46.0 \\
\hline Stable disease & 5.3 & 18.0 \\
\hline Progression & 41.3 & 30.0 \\
\hline Overall response rate (ORR) & 53.3 & 52.0 \\
\hline Disease control rate (DCR) & 58.6 & 70.0 \\
\hline
\end{tabular}

Table 4 Clinical outcomes G719X mutation - S768 I mutation - complex mutation treated with TKI 


\begin{tabular}{|c|c|c|c|c|c|c|c|}
\hline Mutartox & STUDY (RETEREXCE) & 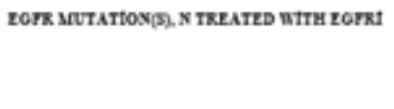 & rornt USED & $\begin{array}{l}\text { OKR } \\
\text { (c) }\end{array}$ & $\begin{array}{l}\text { DCE } \\
\text { (c) }\end{array}$ & 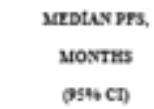 & $\begin{array}{c}\text { Mazotux os, } \\
\text { sostrs } \\
\text { (956 cD }\end{array}$ \\
\hline \multirow[t]{6}{*}{ G19x } & Cow et a (20) & $676 x,=0 m$ & 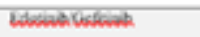 & $16 \mathrm{~m}$ & 7205 & 60 & Se \\
\hline & 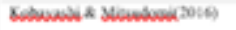 & $6734 x=148$ & 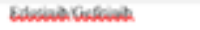 & 6535 & $12 \mathrm{as}$ & $\mathrm{sx}$ & NR \\
\hline & Kence dawh & $678 \times a=5$ & 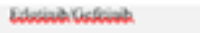 & sachs & NR & 9 & SR. \\
\hline & Tase alcois? & 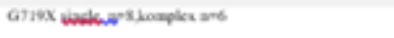 & absint & $n \times m$ & NR & us & ass \\
\hline & Gowalas id. & G719X $==36$ & Edwiat. & 47:56 & 5536 & 4.9 & ns \\
\hline & Cowosest al. & $6718 x=24$ & absion & $\operatorname{sen}$ & mens & 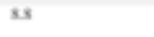 & 21.6 \\
\hline \multirow[t]{6}{*}{ s76st } & 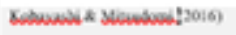 & SWLW"12 & 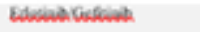 & $\cos$ & $\operatorname{secs}$ & $\mathrm{sx}$ & NR \\
\hline & Caw et disois?. & Swater & 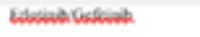 & 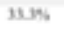 & $\cos \pi$ & $\mathrm{sx}$ & $\mathrm{NR}$ \\
\hline & Kwe dawh & swewn't & 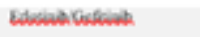 & aens & ans & 1 & NR \\
\hline & Laket al (20is). & 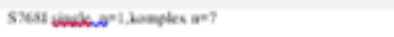 & abowat & 1005 & 1005 & 14.7 & NR \\
\hline & Cowisest al. & sxesi ans & Livinat & tas & 5535 & 9.7 & 16.7 \\
\hline & Gowativen 2. & 5xs4 ant & abewat & 1606 & $\operatorname{sen}$ & 3.1 & 34.7 \\
\hline \multirow[t]{6}{*}{ cosentex } & subua (2006) & 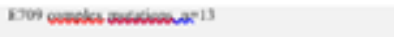 & 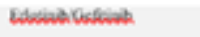 & saces: & $72 \times 6$ & 62 & 203 \\
\hline & 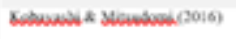 & 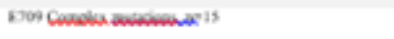 & 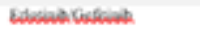 & sums: & 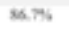 & $\mathrm{xx}$ & NR \\
\hline & Casaet a (DN6) & sxesi-Lsssicam 4 & Edwial Gstiving. & $20 \mathrm{css}$ & raes & 2.7 & 145 \\
\hline & Cowet a (30is? & $5 \times 244-6718 x=50$ & 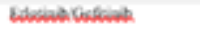 & sans: & $100 \%$ & $\mathrm{sx}$ & SiR \\
\hline & Gowewes 2. & 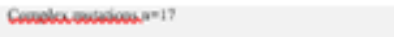 & Edvina. & rass & $\times 2 \times 5$ & 11.7 & 200 \\
\hline & Cosowest al. & 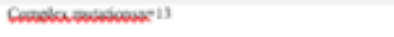 & abowit & 6L: 5 & cans & 18.7 & 319 \\
\hline \multirow[t]{7}{*}{ EX 20 tssexttox } & Sact al (2016) & 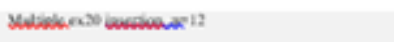 & Edvinat Gestowith. & 835 & $38 \times 6$ & 20 & $16 \%$ \\
\hline & Bsoulabete al (2014). & 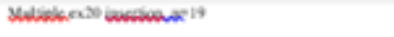 & 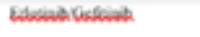 & $\operatorname{sen}$ & sos ons & 2 & 95 \\
\hline & Kenes 4 coth & 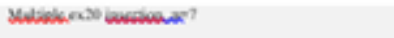 & 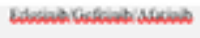 & aens & ans & 19 & YR \\
\hline & Lank ed al (2019) & 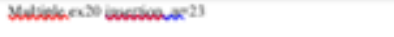 & abewit & s.r. & $650 \mathrm{sis}$ & 2.7 & 92 \\
\hline & Cowevest d. & 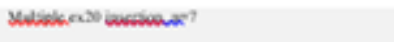 & wewat & $2 \times 3 \times$ & $62 \pi 6$ & 70 & 24.6 \\
\hline & Covelent 2. & 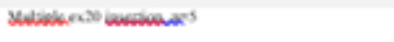 & Golevint & $\cos$ & 62.96 & 120 & 285 \\
\hline & Govelest d. & 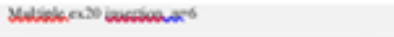 & absiat & $\operatorname{sen}$ & $\leqslant 50$ & 8.7 & 31.4 \\
\hline
\end{tabular}

\section{Figures}




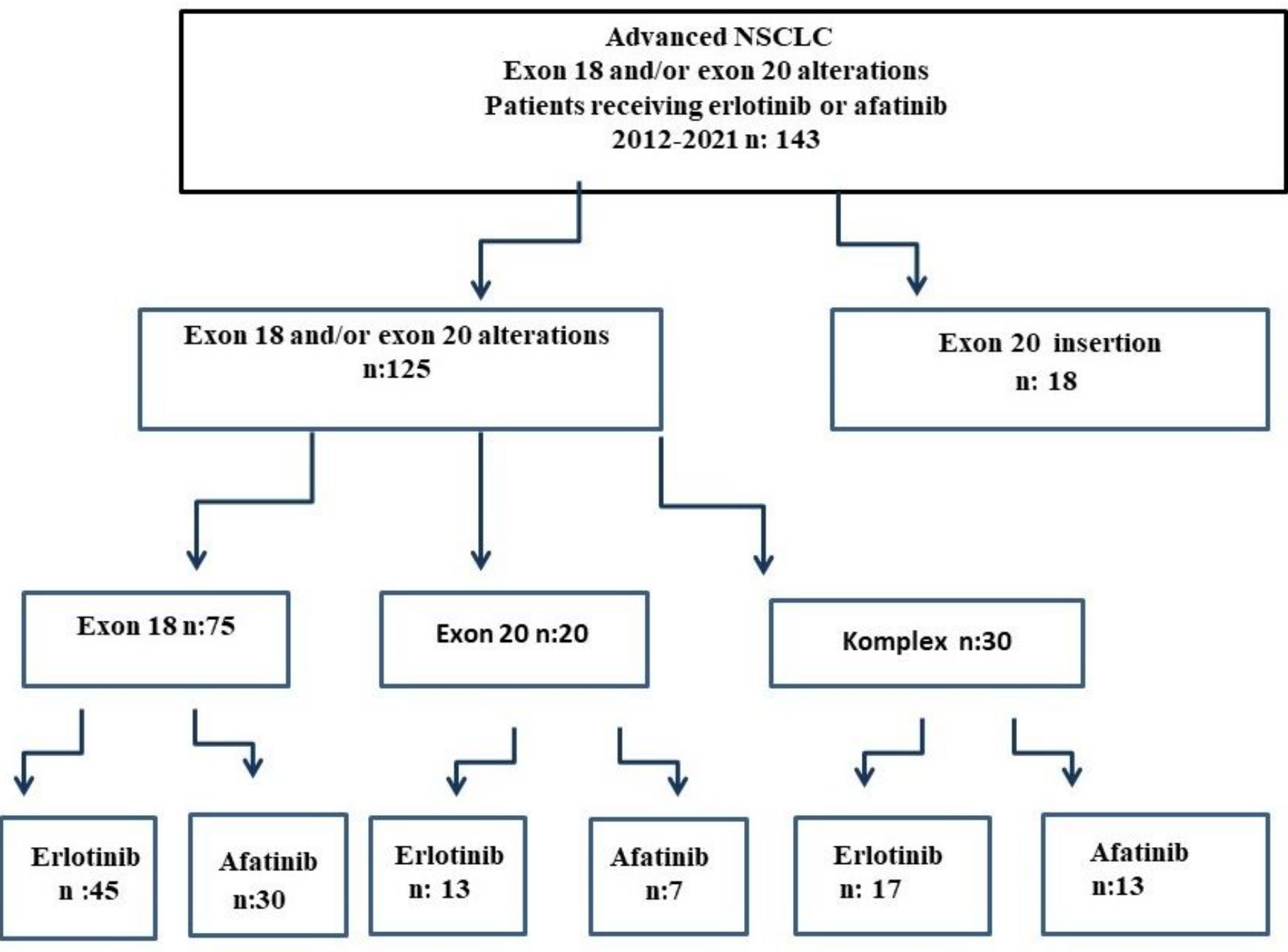

Figure 1

Flow chart of the study 


\section{Figure 2}

A

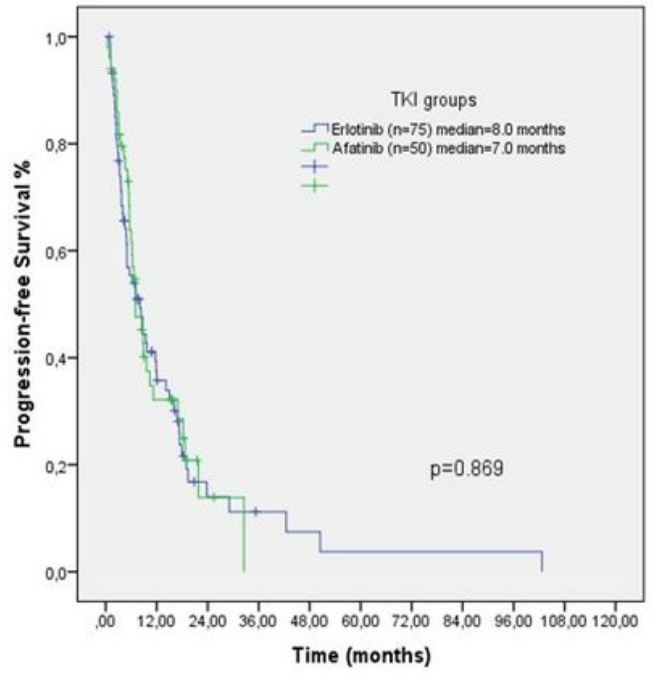

$\begin{array}{llllllllll}\text { Erlotinib } & 43 & 11 & 1 & 1 & 1 & 0 & 0 & 0 & 1\end{array}$

Afatinib $\quad 30 \quad 4 \quad 1$
B

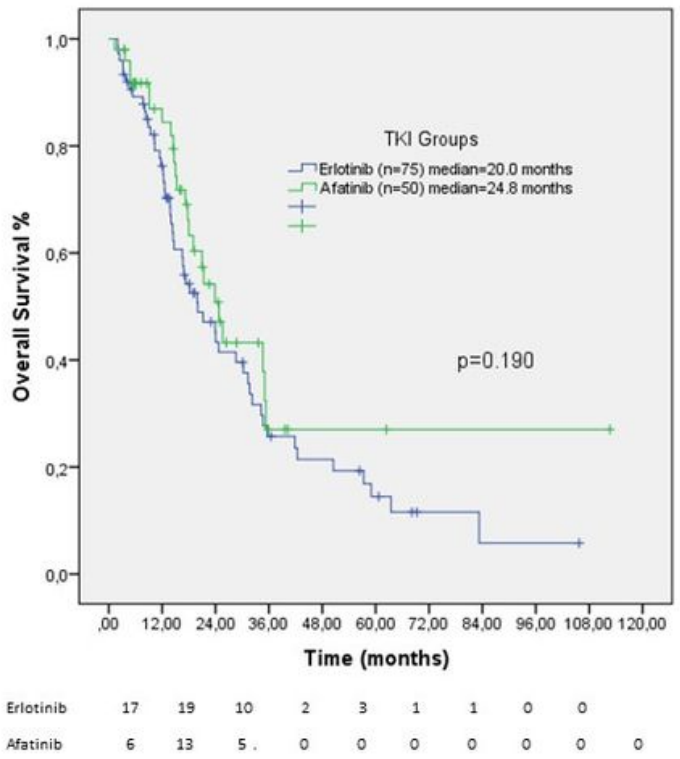

\section{Figure 2}

Kaplan-Meier curves for (A) PFS of patients who received erlotinib and afatinib Kaplan-Meier curves for (B) OS of patients who received erlotinib and afatinib

Figure 3

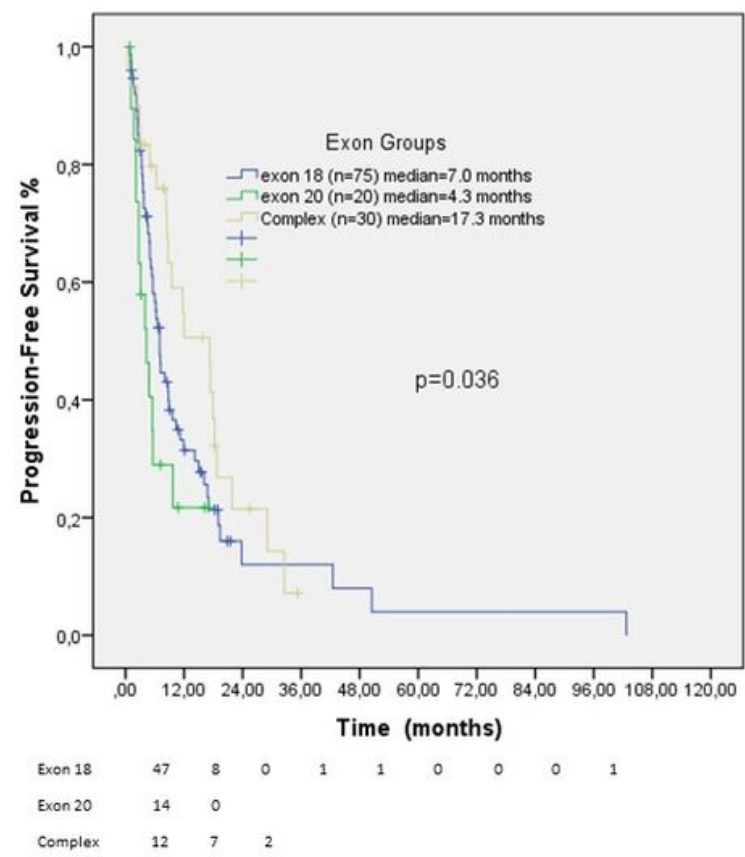


Figure 3

Kaplan-Meier curves for (A) PFS of patients havings exon 18, exon 20 and complex mutations

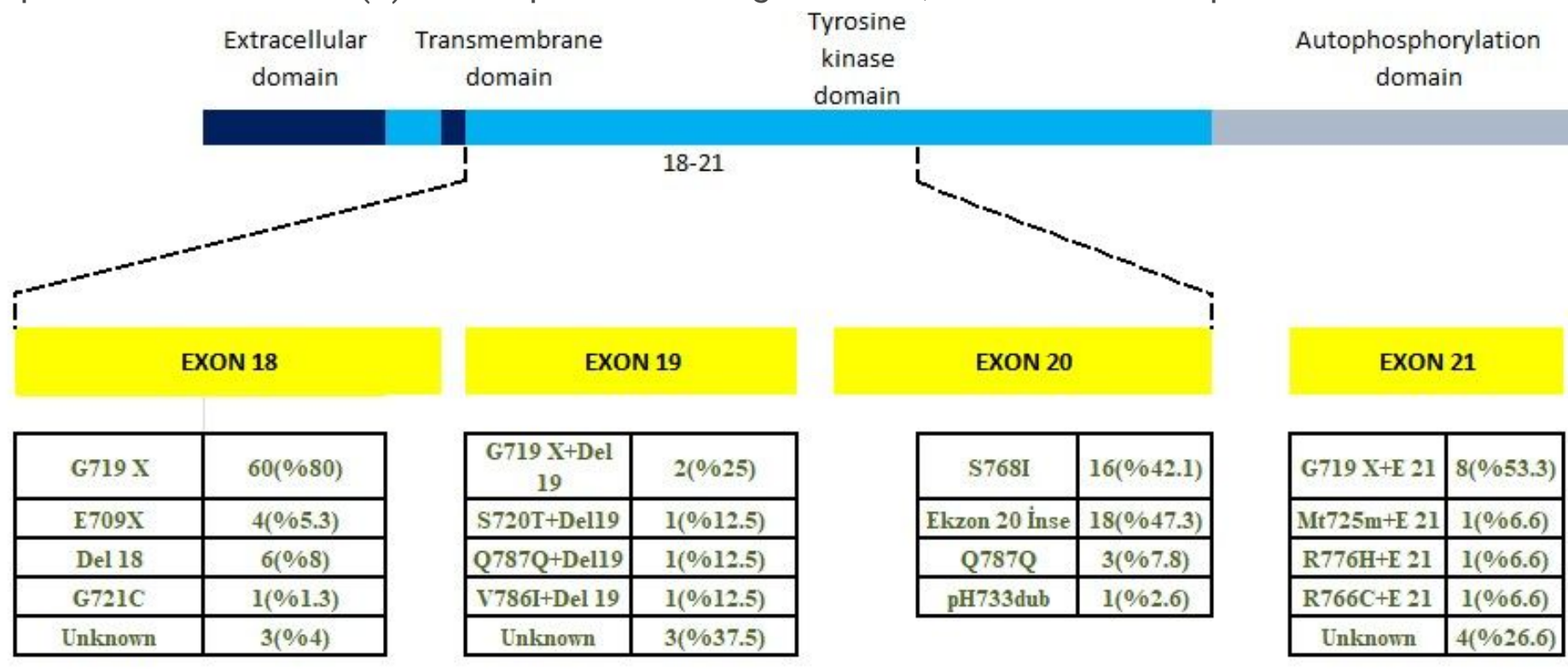

\section{Figure 4}

Molecular distributions of rare mutations 